UDC 578.891.

\title{
SYNTHESIS AND CHARACTERIZATION OF ANTIGENIC PEPTIDE OF SHEEP POX DISEASE
}

\author{
Zeynep MUSTAFAEVA
}
Yildiz Technical University, Chemical and Metallurgy Faculty, Bioengineering Department, 34220, Istanbul/Turkey zmustafaeva@yahoo.com

\begin{abstract}
The aims of this study are to synthesize the Sheep-Pox Diseases' 92-118 antigenic peptide sequence epitope belonging to P32 major protein by microwave supported solid phase peptide synthesis method, characterize the synthesized peptide and bind it covalently to polyacrylic acid polymer (PAA). This polymer showing adjuvant properties, peptide-polymer conjugates synthesize with constant peptide ratios and various polymer ratios and characterize the peptide-polymer conjugate in order to prepare a vaccine prototype for the aforementioned disease is another purpose of the study.
\end{abstract}

Keywords: sheep-pox disease, solid phase peptide synthesis, bioconjugation

\section{INTRODUCTION}

Sheep-Pox is an extremely contagious disease caused by Sheep-Pox Virus (SPPV) belonging to Capripoxvirus genus. SPPV is a big ( $>200$ $\mathrm{nm})$ virus with a linear, double stranded 150 $\mathrm{kb}$ sized genome. SPPV is a notifiable disease by definition of the World Health Organization (WHO) [1-3].

Vaccination is the most economic and efficient way to control Sheep-Pox Disease and increase ovine productivity in endemic countries. Even though many animals benefit from live and inactive vaccines against SheepPox Disease, studies aimed at developing a new generation of vaccines are still underway $[4,5]$. Peptide vaccines, which is a type of new generation vaccine system, have no disadvantages that classic vaccines exhibit and have been on the agenda of academics in the past few years[6, 7].

The basis of the new generation of synthetic peptides is the synthesis of peptides that constitute antigenic regions of pathogen spreading and link synthesized peptides to carriers of polymers and proteins with adjuvant properties through various procedures aimed at obtaining a strong immune response [8-10]. Traditionally, the synthesis of determined antigenic peptide epitope to be used in the new generation of synthetic vaccines is grouped into two categories. These include the classical peptide solution synthesis method and the solid phase peptide synthesis method. Even though classical methods are still relevant in pharmaceutical industry due to short-term peptide series synthesis, the very technique is slow, problematic and time consuming. Solid phase peptide synthesis (SPPS) method allows to get larger and more complex peptides synthesized with high purity and yield [11-13].

Solid phase peptide synthesis consists of 3 basic steps as follows: removal of protection, activation of carboxyl group and formation of peptide bond. These steps are called deprotection, activation and coupling respectively and observed at all amino acids until the desired peptide series is obtained. In the last step, the protective group of final amino acid added can be removed (final deprotection) to get the $\mathrm{N}$ - end freed. The application of microwave in peptide synthesis goes back to 1992, and the microwave-backed peptide synthesis has become one of the most commonly used methods in research works studying the peptide chemistry for synthesizing both routine and complex peptides. Throughout the peptide synthesis, the 
microwave energy is the only one to radiate during the reaction within a specified time limit or until the environment reaches a certain temperature. The vibrating property of the microwave prevents the formation of aggregations that arose from intervening of chains and deletions caused by absence of added amino acids on the long peptide chain growing on top of resin [11, 14-16].

In the paper, antigenic peptide epitope of P32 major proteins' 92-118 peptide sequence of the stated Sheep-Pox Disease [17] was synthesised via microwave-backed solid phase peptide method while purification and characterization were performed with the help of LC-MS, GPC, Zeta Sizer and Fluorescence Spectroscopy. In order to obtain water soluble conjugates which can be used as vaccine prototype, the synthesised peptide was covalently bounded to an adjuvant PAA polymer via cross-linker, so the obtained peptide-polymer bioconjugates were described through the use of GPC, Zeta Sizer and Fluorescence analysis.

\section{MATERIAL-METHOD}

\section{Material}

Wang resin charged with Lys which is required for the synthesis of synthetic 92-118 peptide sequence (EAKSSIAKHFSLWKSYADADIKNSENK, $\mathrm{NH}_{2-}$ Glu - Ala - Lys - Ser - Ser - Ile - Ala - Lys His - Phe - Ser - Leu - Trp - Lys - Ser - Tyr Ala - Asp - Ala - Asp - Ile - Lys - Asn - Ser Glu - Asn - Lys -COOH) belonging to P32 major antigen of Sheep-Pox Virus used in the study. Note that amino acids and linker reagents were obtained from Nova Biochem and DMF, DCM, TFA, HOBt, HCTU, DIEA, NMP while Fmoc-protected amino acids obtained from Sigma Aldrich. The carrier Polyacrylic Acid (PAA) polymer, as well as 1ethyl-3-(3-dimethylaminopropyl)-

carbodiimide hydrochloride (EDC) obtained from Sigma; disodium hydrogen phosphate $\left(\mathrm{Na}_{2} \mathrm{HPO}_{4}\right)$, sodium hydroxide $(\mathrm{NaOH})$, sodium chloride $(\mathrm{NaCl})$ obtained from Fluke; sodium hydrogen phosphate $\left(\mathrm{NaH}_{2} \mathrm{PO}_{4}\right)$ and hydrochloride acid $(\mathrm{HCl})$ obtained from Riedel-de Haën. Ultra-pure water obtained from Millipore MilliQ Gradient system was used as solvent for any solution prepared.

\section{Peptide synthesis}

The antigenic property of synthetic 92-118 peptide sequence belonging to P32 major antigen of Sheep-Pox Disease is referred to in the literature[17].

The synthesis of the antigenic peptide in this study was performed with a microwavebacked solid phase peptide synthesis device
(Liberty (CEM, USA)). The synthesis of the peptide was carried out with microwavebacked SPPS technique inside DMF, using 2(6-chloro-1H-benzotriazole-1-yl)-1,1,3,3tetramethyluronium hexafluorophosphate/1hydroxybenzotriazole (HCTU/HOBt) as an activator, N, N-diisopropylethylamine/Nmethyl-2-pyrrolidinone (DIEA/NMP) as an activator base and piperidine as a de-protector (DEP). Also, Wang resin was inflated inside DMF prior to the synthesis.

\section{Removal of peptide from resin (cleavage)}

In order to deprive the peptide of the solid support, the obtained resin-based peptide was slowly mixed inside the cleavage cocktail [(TFA/thioanisole/EDT/water), (87,5/5/2,5/5 $\mathrm{mL},(\mathrm{v} / \mathrm{v})]$ for 3 hours at room temperature with the help of mixer. Cold ether $\left(-20^{\circ} \mathrm{C}\right)$ was used for precipitation and removal of peptide. After the peptide was centrifuged, the precipitation procedure was repeated and the final precipitate washed and then dried.

\section{Peptide purification and description}

The synthesised peptide was analysed and purified by means of preparative HPLC (Shimadzu) and Shimadzu PRC-ODS C-18 column $30 \times 2.1$ column with UV detector.LCMS system (Shimadzu LC MS 2010 EV). Electro Spray Ionizing (ESI) probe and Teknokroma Tracer Exel 120 ODS-A, C-18 column $(20 \mathrm{~cm}$ length and $0.21 \mathrm{~cm}$ inlet diameter) were used to describe the peptide.

The 92-118 sequenced synthetic peptide belonging to P32 major antigen of Sheep Pox 
Virus (EAKSSIAKHFSLWKSYADADIKNSENK) is composed of 27 amino acid residues. The $13^{\text {th }}$ hydrophobic and non-polar amino acid Tryptophan (Trp) absorbs UV radiation at 280 nm.s' which gives the sequence a fluorescent property. Other hydrophobic and non-polar amino acids of the sequence --- Phenylalanine (Phe) and Tyrosine (Tyr) absorb UV radiation similar to Trp; however, their absorbance values and quantum yield proved to be lower than that of Trp. Note that with its' -OH group, Tyr contributes to the Hydrogen bonds that contribute to peptide formation. All of three aromatic amino acid mentioned above absorb UV radiation at $260-280 \mathrm{~nm}$ wavelengths with the double conjugate bonds they have to arise from a specific peak for each of the amino acids. Amino acids which include highly hydrophobic side chains such as Alanine (Ala) and Leucine (Leu) cluster with each other in an aqueous solution and help the peptide to get stabilized with hydrophobic interactions. Sequences that polar side chains follow such as Serine (Ser), Asparagine (Asn) raise the solubility of the peptide because of their hydrophilic properties which allow them to get dissolved in water better as compared to other amino acids. Also, the hydroxyl group of Serine and amide group of Asparagine form Hydrogen bonds with water which is crucial for peptides of three dimensional structure. Given the covalent modification of the peptide

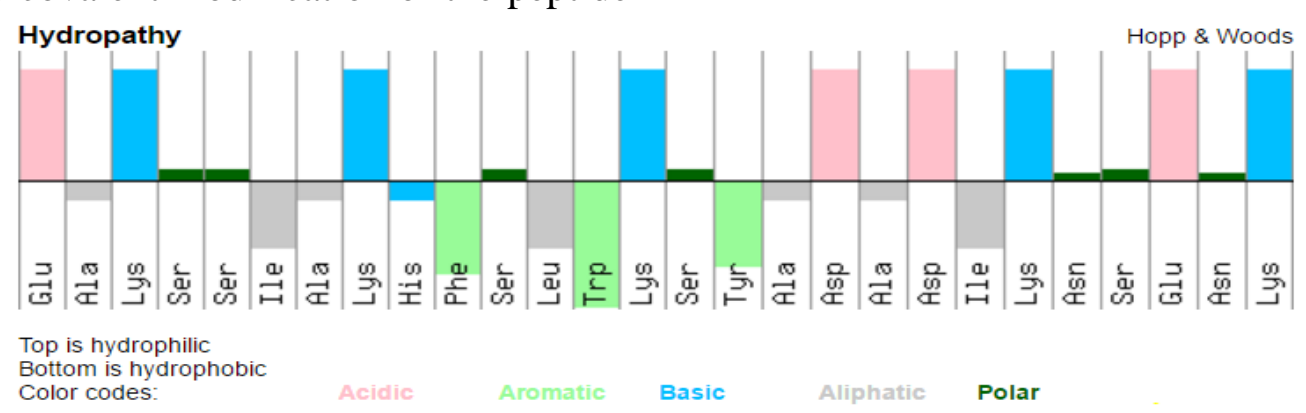

Fig.1. Schematic Representation of Hydrophilic and Hydrophobic Amino Acid Residues

\section{Peptide-Polymer Bioconjugate Synthesis}

In this study, PAA-peptide bioconjugates were synthesised with constant peptide concentrations and increasingly polymer concentrations $\left(\mathrm{n}_{\mathrm{PAA}} / \mathrm{n}_{\text {peptide }}=0.022 ; 0.044\right.$; 0.066) using 1-ethyl-3-(3-dimethylobtained. Dry EDC at 2:1 ratio (EDC:PAA) was added on top of the solution to activate the sequence and the conjugation mechanism, the most crucial amino acids are as follows: Aspartic acid (Asp), Glutamic acid (Glu), Histidine (His) and Lysine (Lys). It should be noted that 5 Lys amino acid on a peptide sequence not only provides the protein of hydrophilic property with their $-\mathrm{NH}_{2}$ functional groups but these groups also allows the peptide to get outwards and thus allow it to interact with water molecules. Note that Asp and Glu side chains contain - $\mathrm{COOH}$ functional groups whose $\mathrm{pKa}$ values are so low $\left(\mathrm{pKa}_{\mathrm{Asp}}\right.$ $=3.86, \mathrm{pKa}_{\mathrm{Glu}}=4.25$ ) and charges are protected when they join the structure of the peptide even at the physiological $\mathrm{pH}(-)$. With their high polarity and solubility, the amino acids are located on outer regions of the peptide and contribute to ionic and hydrogen bond formations. Imidazole group that HIS carries can both donate and accept $\mathrm{H}^{+}$. The pKa value of imidazole ring ( $\mathrm{pKa}=6.0$ ) on the side chain is very close to the physiological $\mathrm{pH}$ which provides HIS of amino acid with greater buffering effect[18, 19].

The isoelectric point and net charge at $\mathrm{pH}=7$ values for the synthesized peptide had been measured with Innovagens' peptide calculator which read 9.52 and 1.1 respectively. It revealed that the peptide is highly water soluble and its hydrophilic and hydrophobic amino acid residues are given in Fig. 1. aminopropyl) of carbodiimide cross binder. PAA polymer was dissolved in $0.1 \mathrm{M}$ phosphate buffer solution at $\mathrm{pH}=5$, and this value was set after the solution had been over and 3 different polymer concentrations carboxyl groups of the polymer, then the solution had been mixed for an hour at room 
temperature. Following the activation of the carboxyl groups of the polymer, an appropriate concentration of ready synthetic peptide dissolved in $0.1 \mathrm{M}$ phosphate buffer solution was added to the polymer solution, and the blend had been mixed overnight at $4^{\circ} \mathrm{C}$ with magnetic mixer. The $\mathrm{pH}$ values of mixtures were set at 7.0 and the blend had been mixed for another 4 hours at $4^{\circ} \mathrm{C}$. Bioconjugates' varied molar ratios $\left(\mathrm{n}_{\mathrm{PAA}} / \mathrm{n}_{\text {peptide }}=0.022 ; 0.044 ; 0.066\right)$ were calculated as per the equation 2.1[20].

$$
\mathrm{n}=\mathrm{c} . \mathrm{NA} / \mathrm{M}
$$

Symbols' representations are as follows: $\mathrm{M}$ is a molecular weight of the component, NA is an Avagadros' Number and $\mathrm{C}$ is a concentration of the component in terms of $\mathrm{mg} / \mathrm{mL}$.

Characterizations of Peptide and PeptidePolymer Conjugate with Size Exclusion Chromatography (SEC)

Size exclusion chromatography with triple detector (refractive index (RI) $660 \mathrm{~nm}$ ), Right Angle Light Scattering (RALS, $670 \mathrm{~nm}$ ) detector and Ultraviolet (UV,280 nm) detector were used in the peptide and peptide-polymer bioconjugate analysis. Peptide, polymer and peptide-polymer bioconjugate were separated by means of Shim-Pack Diol 300 column (500 $\mathrm{mm}$ length, $7.9 \mathrm{~mm}$ inlet diameter). Polymer standards with a known molecular weight and size were used for column calibration. Chromatographic separation was performed at room temperature with $1.0 \mathrm{~mL} / \mathrm{min}$ flow rate.
Phosphate buffered saline (PBS) was prepared with ultra-pure water, $50 \mathrm{mM}$ phosphate and $150 \mathrm{mM}$ sodium chloride and then used as mobile phase. $\mathrm{NaN}_{3}$ was added to the mobile phase in order to prevent contaminations. This phase was also filtered through $0.45 \mu \mathrm{m}$ Millipore cellulose nitrate filter and degassed before use.

\section{Characterizations of Peptide and Peptide- Polymer Conjugate with Fluorescence Spectroscopy}

Fluorescence emission spectra of peptide, polymer and peptide-polymer conjugate were obtained with the help of QM-4/2003 Quanta Master Steady State Spectrofluorometer (Photon Technology International, Canada). Analyses were carried out in quanta counting mode with a slit gap of $3 \mathrm{~nm}$ for excitation and emission monochromators. Excitation was performed in $270 \mathrm{~nm}$ and spectra measured between 280-500 nm's.

\section{Particle Size Analysis of Peptide and Peptide-Polymer Conjugates}

Particle size analyses of peptide, PAA and polymer-peptide conjugates were performed with Dynamic Light Scatter Technique with Zetasizer Nano ZS (Malvern Instruments, UK) equipped with $4.0 \mathrm{mV}$ He-Ne laser lamp (633 $\mathrm{nm})$ at $25^{\circ} \mathrm{C}$ with $\pm 0.1{ }^{\circ} \mathrm{C}$ sensitivity. The solvent had a viscosity value of $0.08872 \mathrm{cP}$, a refractive index of 1.330 and all of the samples were run through $0.20 \mu \mathrm{m}$ filter (Sartorius) prior to analysis. All of the analyses were retried three times.

\section{RESULT AND DISCUSSION}

\section{Synthesis and Characterization Results of P-32 Major Protein and 92-118 Sequenced Peptide Series}

Molecular weight of the synthesised peptide was analysed by means of LC-MS apparatus which gave a value close to the theoretical $\mathrm{Mw}=3068.35$ molecular weight. GPC UV Chromatogram of the peptide given in Fig. 2.a shows that the peptide left the column at $23^{\text {rd }}$ minute having a single peak. It can be seen that the peptide shows fluorescence properties due to Tryptophan (Trp,W), Tyrosine (Tyr, Y) and Phenyl Alanine (Phe, F) in its structure from the $\lambda_{\max }$ value on the Fluorescence Spectrum of the peptide given in Fig. 2.b. From the size graph measured in Zeta Sizer apparatus given in Fig. 3 it follows that the size of the peptide is $4.1 \mathrm{~nm} . \mathrm{s}^{\text {' bearing in mind }}$ the $\mathrm{Z}$-ave value. 
(a)

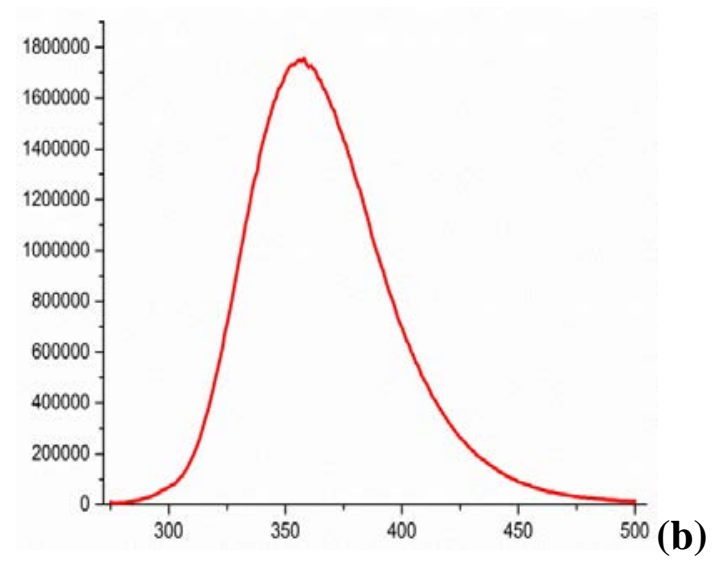

Fig. 2. a) GPC-UV Chromatogram of the Peptide; b) Fluorescence Spectrum of the Peptide

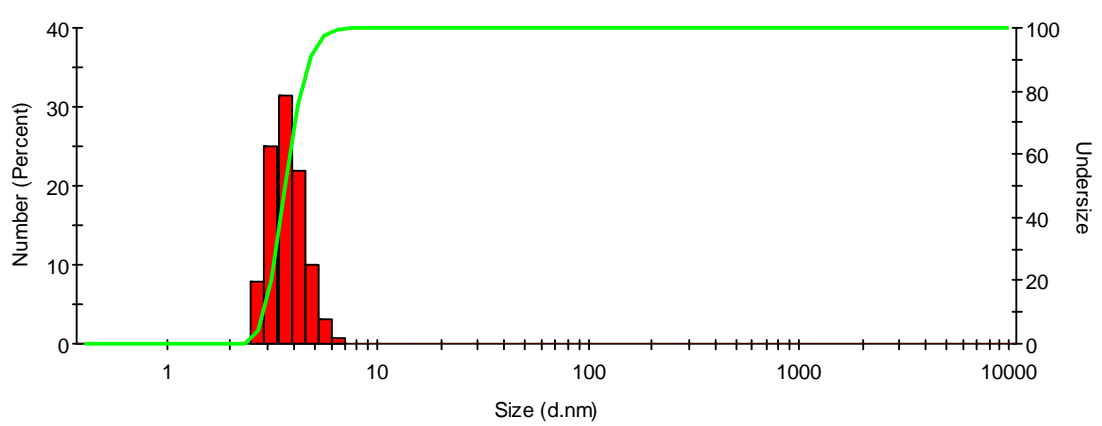

Fig. 3. Size Graph of the Peptide

\section{Peptide-Polymer Conjugation Results and}

\section{Discussion GPC Measurements}

UV and RALS Chromatograms obtained from GPC measurements of peptide, PAA and peptide-polymer conjugates in various concentrations $\left(\mathrm{n}_{\mathrm{PAA}} / \mathrm{n}_{\text {peptide }}=0.022 ; 0.044\right.$; 0.066) are given in Fig. 4.a and 4.b respectively. It can be seen from the chromatogram obtained at RALS detector which is dependent on molecular weight that

PAA gives a peak at $10^{\text {th }}$ minute term and the weak peak obtained at UV chromatogram belongs to PAA. It is obvious from the UV chromatogram of the peptide that the peak leaves relatively later than PAA polymer, at $23^{\text {rd }}$ minute. Due to its low molecular weight the peptide shows no peak at RALS chromatogram.
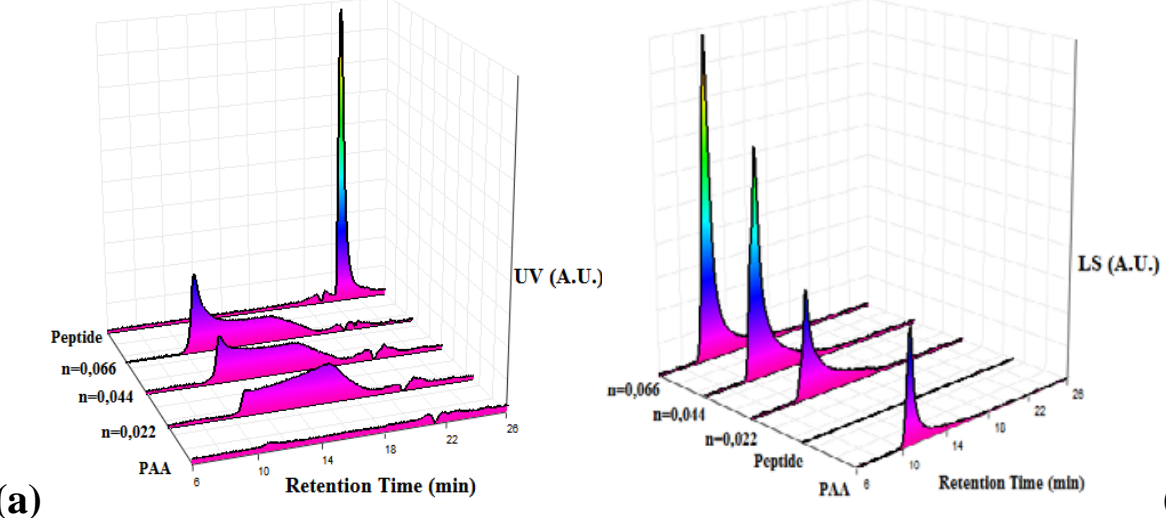

(b)

Fig. 4.a) GPC-UV chromatogram b) GPC-RALS chromatogram of peptide, PAA and PAA-peptideconjugates $\left(\mathrm{n}_{\mathrm{PAA}} / \mathrm{n}_{\text {peptide }}=0.022 ; 0.044 ; 0.066\right)$ 
Bioconjugates with varying ratios $\left(\mathrm{n}_{\mathrm{PAA}} / \mathrm{n}_{\text {peptide }}=0.022 ; 0.044 ; 0.066\right)$ were synthesised by constant peptide and increase of polymer concentrations. The polymer and conjugates leaving the column as is seen in Fig. 4.a, it shows comparative UV chromatograms obtained from GPC analyses of peptide, PAA and peptide-PAA conjugates. Changes in the peak area with the ratios of components are shown in Fig. 5. It is obvious that the peak area rises as the $\mathrm{n}_{\mathrm{PAA}} / \mathrm{n}_{\text {peptide }}$ increases. A trail on the UV chromatograms of the PAA polymer can be seen which is caused by high PDI value of the polymer. It is believed that peptide may be bound when forming conjugates with polymer, for it

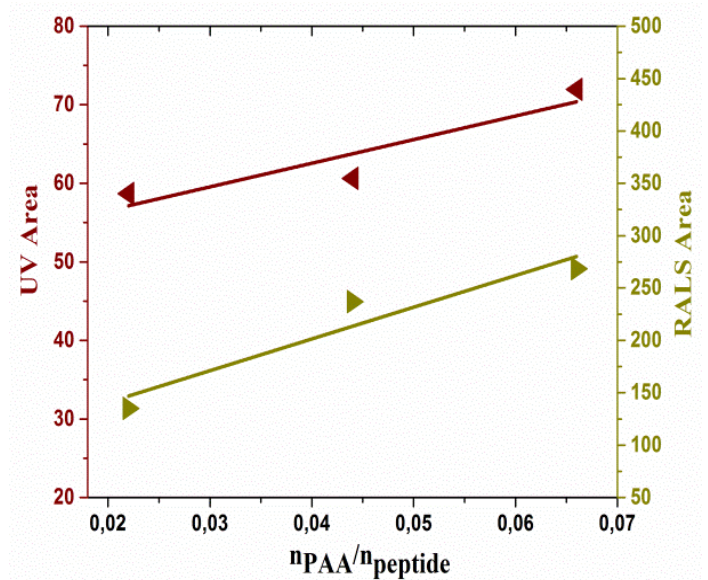

Data obtained from GPC chromatograms show that peptide-polymer bioconjugates were formed successfully.

\section{Particle Size Measurements}

Particle size measurements of polymer, peptide and polymer-peptide bioconjugates are given in Fig.6. Sizes of the bioconjugates are expected to be greater than those of free polymer and free peptide, as well as contains both $-\mathrm{NH}_{2}$ and $-\mathrm{COOH}$ functional groups. Using both RALS and UV chromatograms and literature [21], one can assume that these peptide oligomers may be bound on the PAA polymer.

As the GPC-UV chromatogram of bioconjugates is observed, it can be seen that no peaks were obtained at a moment where peptide gave peaks. Note that every peptide molecule was used during conjugation reaction. From the RALS chromatograms of bioconjugates given in Fig. 4.b it is obvious that conjugates give peaks at the moment where PAA gave peaks and changes in the peak area with varying $n_{\mathrm{PAA}} / \mathrm{n}_{\text {peptide }}$ ratio can be seen in Fig. 5.

$$
\begin{gathered}
\text { Fig. 5.GPC-UV and RALS peak areas } \\
\text { of bioconjugates } \\
\left(\mathrm{n}_{\mathrm{PAA}} / \mathrm{n}_{\text {peptide }}=0.022 ; 0.044 ; 0.066\right)
\end{gathered}
$$

components that form the conjugate by binding them via covalent bonds. Z-Ave values for every bio-conjugate ratio are given in Fig.6 which says that these values are greater than that of $Z$-Ave value of free polymer. A comparison of Z-Ave values of the bio-conjugates reveals a linear increase of ZAve values in the polymer concentration. This means that Z-Ave values obtained from Zeta Sizer are consistent with data obtained from GPC-RALS chromatograms. 


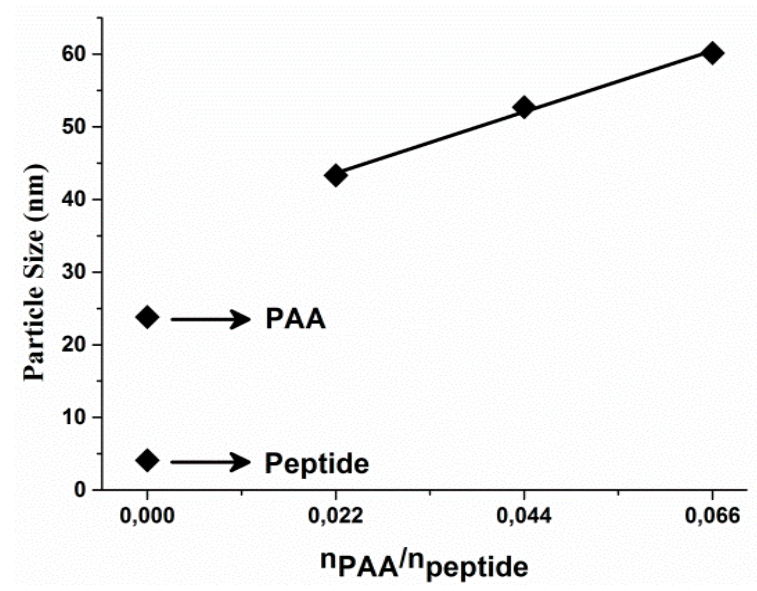

Fig.6.Particle size of peptide, PAA and bioconjugates $\left(\mathrm{n}_{\mathrm{PAA}} / \mathrm{n}_{\text {peptid }}=0.022\right.$; $0.044 ; 0.066)$

\section{Fluorescence Measurements}

Fluorescence spectra of the peptide and conjugates with various ratios $\left(\mathrm{n}_{\mathrm{PAA}} / \mathrm{n}_{\text {peptide }}=\right.$ $0.022 ; 0.044 ; 0.066$ ) are given in Fig. 7. It follows from Fig.2.b that the peptide has a high fluorescence intensity. The literature [22, 23] says that a decrease in the fluorescence intensity and/or a shift at $\mathrm{I}_{\max }$ value is expected to stem from interactions occurring between the peptide and the polymer molecules during bioconjugation reactions. Fig. 7 demonstrates clearly a drop in fluorescence intensity with increasing polymer concentration. In the peptide-polymer conjugate, fluorescent sensitive regions on the peptide get in between the polymer clusters to reduce the fluorescence intensity. Furthermore; the shift in the $\mathrm{I}_{\max }$ value as compared to peptide is another evidence supporting that the conjugation was successful.

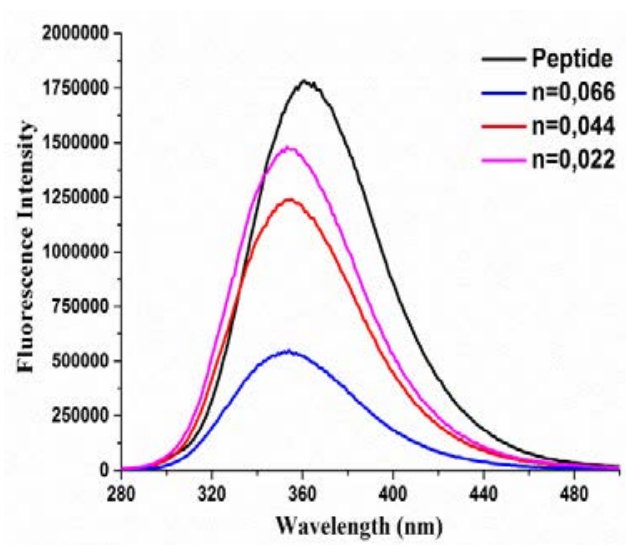

Fig. 7. Fluorescence spectra of bioconjugates with different ratios; $\mathrm{n}_{\mathrm{PAA}} / \mathrm{n}_{\text {peptide }}=0.022 \quad\left(\mathrm{I}_{\text {max }}=353\right.$ $\mathrm{nm}), \mathrm{n}_{\mathrm{PAA}} / \mathrm{n}_{\text {peptide }}=0.044\left(\mathrm{I}_{\max }=355 \mathrm{~nm}\right)$, $\mathrm{n}_{\mathrm{PAA}} / \mathrm{n}_{\text {peptide }}=0.066 \quad\left(\mathrm{I}_{\max }=354 \mathrm{~nm}\right)$ in comparison with equivalent amounts of peptide $\quad\left(I_{\max }=361 \quad \mathrm{~nm}\right) \quad$ in bioconjugates.

\section{CONCLUSION}

In the paper, a research into 92-118 showed that the synthetic peptide of P32 major protein from Sheep-Pox Disease Virus was synthesised with solid phase supported by microwave peptide synthesis method and purified with preparative HPLC. The purified peptide was analysed with the help of LC-MS, GPC, ZetaSizer and Fluorescence
Spectroscopy. The analysed peptide had later been conjugated with PAA polymer in the presence of EDC cross binder with the following ratios; $\mathrm{n}_{\mathrm{PAA}} / \mathrm{n}_{\text {peptide }}=0.022,0.044$, 0.066 which were later analysed with the help of GPC, ZetaSizer and Fluorescence Spectroscopy. 
All of the analyses performed are consistent with each other to indicate that the synthesis of the peptide and the conjugation of this peptide with PAA polymer in forming a bioconjugate were successful. The results obtained from this experiment are believed to pave the way to the development of synthetic peptide vaccine for Sheep-Pox Disease.

\section{REFERENCES}

1. Zro K., Azelmat S., Bendouro Y., Kuhn J.H., El Fahime E., Ennaji M.M.

PCR-based assay to detect sheeppox virus in ocular, nasal, and rectal swabs from infected Moroccan sheep. Journal of virological methods, 2014, vol. 204, pp. 38-43.

2. Chervyakova O.V., Zaitsev V.L., Iskakov B.K., Tailakova E.T., Strochkov V.M., Sultankulova K.T., Sandybayev N.T., Stanbekova G.E., Beisenov D.K., Abduraimov Y.O. Recombinant Sheep Pox Virus Proteins Elicit Neutralizing Antibodies. Viruses, 2016, vol. 8 no.6, p. 159.

3. Hosamani M., Bhanuprakash V., Kallesh D.J., Balamurugan V., Pande A., Singh R.K. Cell culture adapted sheeppox virus as a challenge virus for potency testing of sheeppox vaccine. Indian journal of experimental biology, 2008, vol. 46, no.10, p. 685.

4. Boumart Z., Daouam S., Belkourati I., Rafi L., Tuppurainen E., Tadlaoui K.O., El Harrak M. Comparative innocuity and efficacy of live and inactivated sheeppox vaccines. BMC Veterinary Research, 2016. vol. 12, no. 1, p. 1.

5. Gülyaz V. and Özdemir S. The determination of immunity and safety of a combined Sheep Pox and peste des petits ruminants vaccine. Pendik Vet. Mikrobiyol. Derg, 2010, vol. 37, no. 1, pp. 3-9.

6. Sesardic D. Synthetic peptide vaccines. Journal of medical microbiology. 1993, vol. 39, no.4, pp. 241-242.

7. Moisa A.A. and Kolesanova E.F. Synthetic Peptide Vaccines, in Insight and Control of Infectious Disease in Global Scenario. P.K. Roy, Editor. 2012. pp. 201-228.

8. Derman S. and Mustafaeva Z.

Particle size and zeta potential investigation of synthetic peptide-protein conjugates. Turkish Journal of Biochemistry, 2015, vol. 40, no. 4, pp. 282-289.

9. Mustafaev M.I. and Mustafaeva Z. Novel polypeptide-comprising biopolymer systems. Technology and Health Care, 2002, vol. 10, no. 3, pp. 217-226.

10. Mustafaev M. Functionally Biopolymer Systems. Sigma Journal of Engineering and Natural Science. 2004, vol. 4, pp. 1-201.

11. Özdemir Ö.Z. and Mustafaeva Z. Development Of Polyelectrolyte Based Bioconjugates Using With Synthetic Viral Peptides. Sigma Journal of Engineering and Natural Sciences. 2011, vol. 29, pp. 65-89.

12. Arayıc1 P.P. New generation protective peptide vaccine models: Development of bioconjugates of rabies viral peptides with various adjuvants, in Bioengineering Department. 2015, Y1ld1z Technical University: İstanbul, p. 1-208.

13. Sewald N. and Jakubke H.D., Peptides: chemistry and biology. 2002, vol. 2., Wiley-Vch Weinheim, pp. 1-543.

14. Derman S., Kizilbey K., Mansuroglu B., Mustafaeva Z. Synthesis and characterization of canine parvovirus (CPV) VP2 W-7L-20 synthetic peptide for synthetic vaccine. Fresenius Environ Bull, 2014, vol. 23(2A), pp. 558-66.

15. Vanier G.S. Microwave-Assisted Solid-Phase Peptide Synthesis Based on the Fmoc Protecting Group Strategy (CEM). Methods Mol Biol. 2013, vol. 1047, pp.235-249. 
16. Özdemir Z. Developing bioconjugates which based on polyelectrolytes, using synthetic viral peptides, in Bioengineerind Department. 2008, Yildiz Technical University: İstanbul, p. 1201.

17. Tian H., Chen Y., Wu J., Shang Y., Liu X. Serodiagnosis of sheeppox and goatpox using an indirect ELISA based on synthetic peptide targeting for the major antigen P32. Virology journal. 2010, vol. 7, (245), pp. 1-4.

18. Eroğlu İ.B. Investigating conjugation reactions between different Alzheimer's amyloid beta peptide sequences with polyelectrolytes, in Bioengineering Department. 2014, Yildiz Technical University: İstanbul, p. 1-272.

19. Kılınç B.Y. Investigation of conjugation reaction synthetic peptides of Influenza A virus with polyelectrolytes by fluorescence resonance energy transfer and the other methods, in Bioengineering Department. 2013, Yildiz Technical University: İstanbul, p. 1-237.

20. Eroglu B.I., Kilinc Y.B. and Mustafaeva Z. Bioconjugation of Hepatitis B antigenic peptide with polymeric carriers through various carbodiimide chemistry. Turkish Journal of Biochemistry, 2011, vol. 36, pp. 222-229.

21. Derman S., Mustafaeva Z. and A. Mamedov A. On Regularities of Conjugation of W1L19 Synthetic Peptide to Polyacrylic Acid Polymer Using EDC as a Cross -Binding Agent. European Journal of Scientific Research, 2016, vol. 138, no. 4, pp. 419-430.

22. Filenko A., Demchenko M., Mustafaeva Z., Osada Y., Mustafaev M. Fluorescence study of $\mathrm{Cu}^{2+}$-induced interaction between albumin and anionic polyelectrolytes. Biomacromolecules, 2001, vol. 2, pp. 270-277.

23. Mustafaev M. Fluorescence study of peptide and protein containing interpolyelectrolyte complexes. Wiley Online Library, 2004, vol. 205, no. 1, pp. 199-208.

\section{СИНТЕЗ И ХАРАКТЕРИСТИКА АНТИГЕННОГО ПЕПТИДА У ОВЕЦ, БОЛЬНЫХ ОСПОЙ}

\section{Зейнеп МУСТАФАЕВА}

Технический Университет Йилдыз, химико-металлургический факультет, отделение биоинженерии, 34220, Стамбул/Туриия

zmustafaeva@yahoo.com

Синтезирован и охарактеризован антигенный пептидный эпитоп против болезни оспы овеи с последовательностью 92-118 основного протеина Р32 в твердой фазе под влиянием микроволн, $u$ ковалентным связыванием синтезированного пептида к полимеру полиакриловой кислоты; определены его характеристики и разработаны пептидно-полимерные конъюгаты, которые могут быть использованы в качестве прототипа вакиины против болезни оспы овец.

Ключевые слова: твердофазный синтез пептидов, биоконъюгация, антигенный пептидный эпитоп, полимер полиакриловой кислоты.

Received 14.06.2017. 